\title{
PENGARUH MOTIVASI TERHADAP HASIL BELAJAR SISWA SEKOLAH MENENGAH PERTAMA
}

\section{THE EFFECT OF MOTIVATION ON STUDENT'S LEARNING OUTCOMES IN FIRST HIGH SCHOOL}

\author{
EVA JULYANTI ${ }^{1}$, INDAH FITRIA RAHMA ${ }^{2}$, OLIVIA DWI CANDRA ${ }^{3}$, HAIRUN NISAH $^{4}$ \\ Fakultas Keguruan dan Ilmu pendidikan (FKIP) Universitas Labuhanbatu \\ Jalan Sisingamangaraja No. 126A, KM, 3,5 Aek Tapa Rantauprapat, \\ email: evajulianti.26@gmail.com
}

\begin{abstract}
Abstrak
Motivasi merupakan salah satu faktor penting yang mempengaruhi belajar dan hasil belajar siswa. Seseorang yang memiliki motivasi mempunyai kecenderungan untuk mencurahkan segala kemampuannya untuk mendapatkan hasil belajar yang optimal sesuai dengan tujuan yang diharapkan. Semakin tinggi motivasi yang dimiliki siswa akan mendorong siswa belajar lebih giat lagi dan frekuensi belajarnya menjadi semakin meningkat, sehingga hasil belajarnyapun meningkat. Tujuan penelitian ini adalah untuk mengetahui bagaimana motivasi belajar matematika siswa, hasil belajar siswa, dan membuktikan apakah ada pengaruh motivasi belajar siswa terhadap hasil belajar. Populasi penelitian ini adalah siswa kelas VIII MASS Irsyadul Islamiah berjumlah 22 orang Siswa. Analisis data menggunakan analisis regresi linier sederhana. Metode pengumpulan data yang digunakan dalam penelitian ini adalah angket (kuesioner), dokumentasi dan observasi. Hasil penelitian menunjukkan bahwa motivasi belajar pada siswa kelas VIII MASS Irsyadul Islamiah sangat positif dan baik dilihat dari prolehan nilai indikator motivasi dan jumlah siswa, siswa motivasi tinggi berjumlah 4 (15\%), sedang $13(68) \%$ siswa dan rendah 5 (17\%) siswa. Sehingga diperoleh bahwa ada pengaruh motivasi belajar terhadap hasil belajar siswa. Berdasarkan hasil penelitian dan pembahasan, disarankan agar guru selalu berusaha membangkitkan rasa percaya diri peserta didiknya, hal ini diharapkan untuk menumbuhkan motivasi siswa untuk belajar, agar siswa termotivasi lebih giat belajar dan memaksimalkan potensinya, dan guna mencapai hasil belajar yang baik.
\end{abstract}

Kata kunci : Motivasi Belajar, Hasil Belajar

\begin{abstract}
Motivation is one of the important factors that affect student learning and learning outcomes. A person who has motivation has a tendency to devote all his abilities to get optimal learning outcomes in accordance with the expected goals. The higher the motivation that the students have, the more active the students will be and the learning frequency will increase, so that the learning outcomes will increase. The purpose of this study was to determine how students' motivation to learn mathematics, student learning outcomes, and prove whether there is an effect of student motivation on learning outcomes. The population of this study were 22 students of class VIII MASS Irsyadul Islamah. Data analysis used simple linear regression analysis. The data collection method used in this research is a questionnaire, documentation and observation. The results showed that the motivation to learn in class VIII MASS Irsyadul Islamah students was very positive and good seen from the results of the value of the motivation indicator and the number of students, high motivation students were 4 $(15 \%)$, medium $13(68) \%$ of students and low $5(17 \%)$ students. So it is found that there is an effect of learning motivation on student learning outcomes. Based on the results of research and discussion, it is suggested that teachers always try to arouse their students' self-confidence, this is expected to foster student motivation to learn, so that students are motivated to be more active in learning and maximize their potential, and in order to achieve good learning outcomes.
\end{abstract}

Keywords: Learning Motivation, Learning Outcomes 


\section{Pendahuluan}

Pendidikan merupakan suatu kebutuhan bagi manusia. Pendidikan merupakan usaha sadar pendidik untuk mewujudkan kemampuan atau keterampilan seseorang atau kelompok agar secara aktif mengembangkan potensi yang dimilikinya. Pendidikan dapat dijadikan bekal seseorang dalam memperbaiki kehidupannya dan melakukan inovasi yang mengarah pada peningkatan kualitas diri. Undang-Undang Nomor 20 tahun 2003 tentang Sistem Pendidikan Nasional Pasal 3 menyatakan bahwa tujuan pendidikan nasional adalah mengembangkan potensi peserta didik agar menjadi manusia yang beriman dan bertakwa kepada Tuhan Yang Maha Esa, berakhlak mulia, sehat, berilmu, cakap, kreatif, mandiri, dan menjadi warga negara yang demokratis serta bertanggung jawab. Tujuan pendidikan ini harus diwujudkan dengan tindakan yang nyata dan logis demi terbentuknya generasi bangsa yang berkualitas. Keberhasilan dari suatu pendidikan dapat ditentukan oleh beberapa komponen penting, diantaranya yaitu guru dan siswa.

Gagne mendefinisikan belajar sebagai suatu proses perubahan tingkah laku yang meliputi perubahan kecenderungan manusia seperti sikap, minat, atau nilai dan perubahan kemampuannya yakni peningkatan kemampuan untuk melakukan berbagai jenis performance (kinerja). Kegiatan belajar merupakan kegiatan yang paling pokok dalam keseluruhan proses pendidikan di sekolah. Berhasil atau tidaknya pencapaian tujuan pendidikan banyak bergantung pada bagaimana proses yang dialami siswa sebagai anak didik dalam belajar. Belajar senantiasa merupakan perubahan tingkah laku atau penampilan, dengan serangkaian kegiatan misalnya dengan membaca, mengamati, mendengarkan, meniru dan lain sebagainya. Belajar juga akan lebih baik kalau si subyek belajar itu mengalami atau melakukannya, jadi tidak bersifat verbalistik. Belajar sebagai kegiatan individu sebenarnya merupakan rangsangan-rangsangan individu yang dikirim kepadanya oleh lingkungan. Dengan demikian terjadinya kegiatan belajar yang dilakukan oleh seorang idnividu dapat dijelaskan dengan rumus antara individu dan lingkungan. Dalam proses belajar mengajar guru dituntut untuk dapat mewujudkan dan menciptakan situasi yang memungkinkan siswa untuk aktif dan kreatif.

Matematika merupakan salah satu mata pelajaran pokok dalam pendidikan di Indonesia. Hal tersebut tercermin dalam setiap jenjang pendidikan dari sekolah dasar sampai perguruan tinggi pasti terdapat pelajaran matematika. Matematika dalam dunia pendidikan merupakan salah satu ilmu dasar yang dapat digunakan untuk menunjang ilmu-ilmu lain seperti ilmu fisika, kimia, komputer, dan lain-lain.

Motivasi adalah usaha yang didasari untuk mengerahkan dan menjaga tingkah seseorang agar ia terdorong untuk bertindak melakukan sesuatu sehingga mencapai hasil atau tujuan tertentu. Motivasi belajar memiliki peranan yang sangat penting dalam pembelajaran, baik dalam proses maupun dalam pencapaian hasil belajar. Motivasi belajar memegang peranan penting dalam memberikan gairah, semangat dan rasa senang dalam belajar, sehingga siswa yang mempunyai motivasi tinggi mempunyai energi yang lebih banyak untuk melaksanakan kegiatan belajar, yang pada akhirnya akan mampu memperoleh prestasi yang lebih baik. Dalam Motivasi belajar yang dimiliki siswa, setiap kegiatan pembelajaran sangat berperan penting untuk meningkatkan prestasi dalam mata pelajaran tertentu. Siswa yang bermotivasi tinggi dalam belajar memungkinkan akan memperoleh hasil belajar yang tinggi pula, artinya semakin tinggi motivasinya, semakin intensitas usaha dan upaya yang dilakukan, maka semakin tinggi Hasil belajar yang diperolehnya. Oleh karena itu, dalam proses pengajaran sangat diperlukan adanya motivasi.

Menurut Biggs \& Tefler motivasi belajar pada siswa dapat menjadi lemah, lemahnya motivasi atau tiadanya motivasi belajar akan melemahkan kegiatan, sehingga mutu hasil belajar akan menjadi rendah. Oleh karena itu, motivasi belajar pada diri siswa perlu diperkuat terus menerus. Dengan tujuan agar siswa memiliki motivasi belajar yang kuat, sehingga hasil belajar yang diraihnyapun dapat optimal[1].

Motivasi belajar sangat penting dalam meningkatan mutu pendidikan, karena dengan adanya motivasi belajar akan meningkatkan hasil belajar siswa. Hal ini menempatkan motivasi belajar pada posisi yang penting di dalam proses pembelajaran, akan tetapi realita di lapangan menunjukan bahwa banyak siswa yang tidak memiliki kemauan belajar yang tinggi pada mata pelajaran matematika. Pada dasarnya motivasi adalah kondisi psikologis yang mendorong seseorang untuk melakukan sesuatu. Dalam proses pembelajaran motivasi dikatakan sebagai pendorong untuk melakukan suatu hal untuk meningkatkan dan memberikan arahan dalam proses belajar.

Hasil belajar adalah kemampuan-kemampuan yang dimiliki peserta didik setelah ia menerima pengalaman belajarnya. Hasil belajar terbagi menjadi tiga ranah yaitu ranah kognitif, ranah afektif dan ranah 
psikomotorik. Ketiga ranah tersebut menjadi obyek penilaian hasil belajar. Di antara ketiga ranah itu, ranah kognitiflah yang paling banyak dinilai oleh para guru di sekolah karena berkaitan dengan kemampuan para peserta didik dalam menguasai isi bahan pengajaran[2]. Salah satu upaya yang dapat dilakukan untuk meningkatkan sumber daya manusia adalah peningkatan mutu pendidikan, baik prestasi belajar siswa maupun kemampuan guru dalam melaksanakan proses pembelajaran. Peningkatan mutu pendidikan diarahkan untuk meningkatkan kualitas manusia seutuhnya melalui olah hati, olah rasa, dan ulah raga agar memiliki daya saing dalam menghadapi tantangan global[3]

Adapun kriteria yang digunakan untuk mengetahui ukuran motivasi belajar siswa ialah sebagai berikut: (1) Baik, apabila siswa tekun dalam menghadapi tugas, ulet dalam menghadapi kesulitan belajar, menunjukkan minat terhadap bermacam- macam masalah, lebih senang bekerja mandiri, cepat bosan pada tugas-tugas yang rutin (menunjukkan sifat kreatif dalam belajar), dapat mempertahankan pendapatnya, tidak mudah melepaskan hal yang diyakini, dan senang mencari dan memecahkan masalah soal-soal. (2) Cukup, apabila siswa kadangkadang tekun dalam menghadapi tugas, kadang-kadang ulet dalam menghadapi kesulitan belajar, kadangkadang menunjukkan minat terhadap bermacam-macam masalah, kadang-kadang lebih senang bekerja mandiri, kadang-kadang cepat bosan pada tugas-tugas yang rutin (menunjukkan sifat kreatif dalam belajar), dan lain-lain. (3) Kurang, apabila siswa tidak tekun dalam menghadapi tugas, tidak ulet dalam menghadapi kesulitan belajar, tidakmenunjukkan minat terhadap bermacam-macam masalah, tidaksenang bekerja mandiri, tidak menunjukkan sifat kreatif dalam belajar, tidakdapat mempertahankan pendapatnya, mudah melepaskan hal yang diyakini, dan tidaksenang mencari dan memecahkan masalah soal-soal[4].

Pada dasarnya motivasi adalah suatu usaha yang disadari untuk menggerakkan, menggarahkan dan menjaga tingkah laku seseorang agar ia terdorong untuk bertindak melakukan sesuatu sehingga mencapai hasil atau tujuan tertentu. Motivasi akan menyebabkan terjadinya suatu perubahan energi yang ada pada diri manusia. Motivasi merupakan hal terpenting yang harus dikembangkan dalam proses belajar mengajar. Karena motivasi memiliki fungsi dan peran yang utama dalam terlaksananya kegitan belajar mengajar untuk mencapai tujuan pembelajaran. Motivasi adalah dorongan atau niat yang kuat dan kesungguhan untuk melakukan sebuah pekerjaan dengan sebaik-baiknya. [5].

Proses pembelajaran akan berhasil apabila siswa mempunyai motivasi dalam belajar. Untuk memperoleh hasil belajar yang optimal, guru dituntut kreatif membangkitkan motivasi dalam belajar siswa. Makin tepat motivasi yang diberikan ke siswa, maka akan berhasil pula pelajaran itu. Dengan kata lain, adanya usaha yang tekun dan terutama didasari motivasi, maka seseorang yang belajar itu akan dapat hasil belajar yang baik. Motivasi belajar merupakan kondisi yang mendorong siswa untuk belajar dengan senang, bergairah dan belajar secara sungguh-sungguh, yang pada gilirannya akan terbentuk cara belajar siswa yang sistematis, penuh konsentrasi dan dapat menyeleksi kegiatan-kagiatannya.

Sedangkan belajar adalah serangkaian kegiatan jiwa raga untuk memperoleh suatu perubahan tingkah laku sebagai hasil dari pengalaman individu dalam interaksi dengan lingkungannya menyangkut kognitif, afektif, dan psikomotorik. Belajar sebagai kegiatan yang berproses merupakan unsur yang sangat fundamental dalam penyelenggaraan setiap jenis dan jenjang pendidikan. Ini berarti bahwa, berhasil atau gagalnya pencapaian tujuan pendidikan itu amat bergantung pada proses belajar yang dialami oleh siswa, baik ketika ia berada di sekolah maupun di rumah[6].

Hasil belajar adalah sejumlah pengalaman yang diperoleh siswa yang mencakup ranah kognitif, afektif, dan psikomotorik. Belajar tidak hanya penguasaan konsep teori mata pelajaran saja, tapi juga penguasaan kebiasaan, persepsi, kesenangan, minat-bakat, penyesuaian sosial, macam-macam ketrampilan, cita-cita, keinginan, dan harapan[7]. Untuk pencapaian hasil belajar yang maksimal siswa harus mencapai ketuntasan indikator dari setiap aspek pembelajaran yang diterapkan oleh guru[8].

Seseorang dapat dikatakan telah belajar sesuatu apabila dalam dirinya telah terjadi suatu perubahan, akan tetapi tidak semua perubahan yang terjadi. Jadi hasil belajar merupakan pencapaian tujuan belajar dan hasil belajar sebagai produk dari proses belajar, maka didapat hasil belajar. Hasil belajar yang dicapai oleh para siswa menggambarkan hasil usaha yang dilakukan oleh guru dalam memfasilitasi dan menciptakan kondisi kegiatan belajar mereka di sekolah. Hal ini menunjukkan bahwa, tujuan usaha guru tersebut diukur dengan hasil belajar siswa.

Adapun tujuan penelitian ini adalah (1) untuk mengetahui seberapa besar motivasi belajar matematika siswa, (2) untuk mengetahui hasil belajar matematika siswa, dan (3) untuk membuktikan ada pengaruh motivasi belajar matematika siswa terhadap hasil belajar. Berdasarkan uraian di atas, maka penelitian tertarik untuk melakukan penelitian dan apakah terdapat hubungan motivasi belajar siswa dengan hasil belajarnya. Oleh karena itu peneliti melakukan penelitian untuk melihat pengaruh motivasi terhadap hasil belajar siswa kelas VIII pada MASS PP Irsyadul Islamiah. 
Hal : $7-11$

\section{Metode Penelitian}

Populasi adalah jumlah keseluruhan dari satuan-satuan atau individu-individu yang karakteristiknya hendak diteliti. Dalam penelitian ini populasinya adalah seluruh siswa kelas VIII yang ada pada Sekolah MASS PP IRSYADUL ISLAMIAH. Menurut Arikunto (2006: 131), Sampel adalah sebagian atau sebagai wakil populasi yang akan diteliti. Jika penelitian yang di lakukan sebagian dari populasi maka bisa dikatakan bahwa penelitian tersebut adalah penelitian sampel[6].

Penentuan Sampel pada dasarnya tidak ada yang mutlak untuk menentukan berapa persen sampel dari populasi yang akan diambil. Teknik pengambilan sampel menggunakan random sampling (undian) karena setiap anggota populasi yang ada didalam sampling frame bersangkutan mempunyai hak yang sama besar untuk dipilih menjadi anggota sampel.

Penelitian ini adalah penelitian kualitatif. Dalam penelitian ini terdiri dari dua variabel yaitu variabel bebas (X) dan Variabel terikat (Y). Variabel bebas dalam penelitian ini adalah motivasi belajar, sedangkan Variabel terikat dalam penelitian ini adalah hasil belajar. Dalam penelitian ini pengumpulan data dengan menggunakan alat pengumpulan data yang sesuai dengan masalah yang diteliti, angket atau kuesioner, dokumentasi, dan observasi.

\section{Hasil Penelitian dan Pembahasan}

Dari hasil penelitian yang di gunakan untuk mengetahui dan menggambarkan mengenai keadaan variabel. Baik itu variabel motivasi belajar maupun hasil belajar siswa. Persiapan awal sebelum penelitian dilaksanakan, diadakan persiapan persiapan menentukan (1) Objek penelitian, objek dalam penelitian ini adalah siswa kelas VIII MASS PP Irsyadul Islamiah. Persiapan untuk instrumen penelitian, Dalam penelitian ini digunakan instrumen untuk mengumpulkan datatentang variabel motivasi belajar (X) terhadap Hasil Belajar Siswa (Y), dalam penelitian ini instrumen yang digunakan adalah angket. (3) Pengumpilan data berupa angket motivasi siswa, angket ini digunakan untuk mengungkap data tentang variabel motivasi belajar. (4) Dokumnetasi. Untuk mengetahui jumlah siswa dan hasil belajar siswa kelas III MASS PP Irsyadul Islamiah yang dijadikan populasi dalam penelitian ini yang kemudian diambil sampelnya maka dilakukan pengambilan daftar nilai siswa secara dokumenter. dan terakhir observasi. Dalam hasil penelitian ini pemilihan pengelompokan minat belajar subjek yang dikategorikan dalam subjek memiliki minat tinggi, sedang dan rendah.

Tabel 1. Tabel Kriteria Pengelompokkan Minat Belajar

\begin{tabular}{|c|c|}
\hline $\begin{array}{c}\text { Kriteria } \\
\text { Pengelompokan }\end{array}$ & Kategori \\
\hline Nilai $\geq$ mean + MASS & Tinggi \\
\hline Mean - SMP $\leq$ nilai $<$ mean + MASS & Sedang \\
\hline Nilai $<$ mean + MASS & Rendah \\
\hline
\end{tabular}

Peneliti mengelompokkan subjek setelah mengitung nilai yang diperoleh dari tes angket minat belajar. Berikut ini adalah tabel 2 hasil pengelompokkan subjek berdasarkan angket minat belajar siswa, antara lain sebagai berikut :

Tabel 2. Tabel Hasil Pengelompokkan Minat Belajar

\begin{tabular}{|c|c|c|}
\hline No & Nama & Motivasi Belajar \\
\hline 1 & 1 & Sedang \\
\hline 2 & 2 & Sedang \\
\hline 3 & 3 & Rendah \\
\hline 4 & 4 & Sedang \\
\hline 5 & 5 & Sedang \\
\hline 6 & 6 & Sedang \\
\hline 7 & 7 & Rendah \\
\hline 8 & 8 & Tinggi \\
\hline 9 & 9 & Rendah \\
\hline 10 & 10 & Tinggi \\
\hline 11 & 11 & Sedang \\
\hline 12 & 12 & Sedang \\
\hline 13 & 13 & Rendah \\
\hline 14 & 14 & Sedang \\
\hline 15 & 15 & Sedang \\
\hline 16 & 16 & Sedang \\
\hline
\end{tabular}


Hal : $7-11$

\begin{tabular}{|l|l|l|}
\hline 17 & 17 & Sedang \\
\hline 18 & 18 & Tinggi \\
\hline 19 & 19 & Rendah \\
\hline 20 & 20 & Tinggi \\
\hline 21 & 21 & Sedang \\
\hline 22 & 22 & Sedang \\
\hline
\end{tabular}

\begin{tabular}{|c|c|}
\hline kategori & jumlah \\
\hline Rendah & 5 \\
\hline Sedang & 13 \\
\hline Tinggi & 4 \\
\hline
\end{tabular}

Berikut jumlah dan angka hasil penelitian minat belajar siswa dilihat dalam bentuk diagram batang berikut :

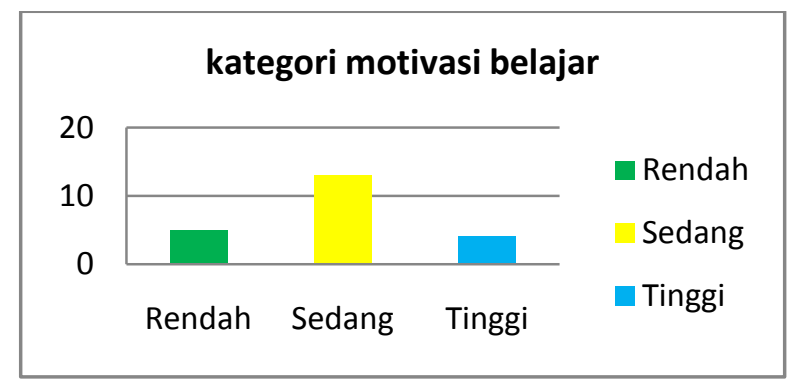

\section{Kesimpulan}

Berdasarkan hasil penelitian dan pembahasannya, maka dapat diambil suatu simpulan sebagai berikut:

1. Tingkat motivasi belajar siswa kelas VIII MASS PP Irsyadul Islamiah sebagian besar berada pada kategori motivasi belajar yang sedang yaitu berjumlah 13 orang $(68,0 \%)$ dari total siswa sebanyak 22 siswa. Sedangkan kategori Tinggi berjumlah 4 orang (15\%) dan Kategori rendah berjumlah 5 orang $(17 \%)$.

2. Terdapat pengaruh motivasi dan Hasil belajar siswa kelas VIII MASS PP Irsyadul Islamiah, dilihat dengan adanya pengambilan data dengan cara observasi, dokumentasi, angket motivasi.

\section{Daftar Pustaka}

[1] Dimyati dan Mudjiono. 1994. Balajar dan Pembelajaran. Jakarta: Depdikbud

[2] Sudjana, Nana. 2009. Penilaian Hasil Proses Belajar Mengajar. Bandung : PT Remaja Rosdakarya

[3] Siregar, S.U. (2016). Perbedaan Kemampuan Pemecahan Masalah Matematika Menurut Teori Belajar Bruner dan Teori Belajar Vigosky pada Kompetensi Dasar Menghitung Luas dan Keliling Bangun Datar kelas V Semester 2 SD Negeri 114375 Binaraga Rantauprapat. Jurnal Pembelajaran dan Matematika Sigma (JPMS). Vol. 2 No.2, hlm. 51-53. 2016

[4] Sardiman A.M., 2014. Interaksi \& Motivasi Belajar Mengajar, Jakarta: PT Raja Grafindo Persada.

[5] Abuddin Nata. 2010. Manajemen pendidikan, Jakarta: Kencana Prenada Madia Group.

[6] Djamarah, Syaiful Basri. Drs. 2002. Psikologi Belajar. Jakarta: PT. Rieneka Cipta

[7] Rusman. 2013. Belajar dan Pembelajaran Berbasis Komputer. Bandung: Alfabeta

[8] Hrp, N.A., Rahma, I.F. 2020. Keefektifan Penerapan Model Pembelajaran Berbasis Proyek Dalam Pencapaian Aspek Kemampuan Representasi dan Komunikasi Matematis Siswa Kelas VI SD Negeri 118296 Beringin Jaya Pinang Damai. Jurnal Pendidikan Matematika (Phi). Vol. 4 No. 2 Tahun 2020 
